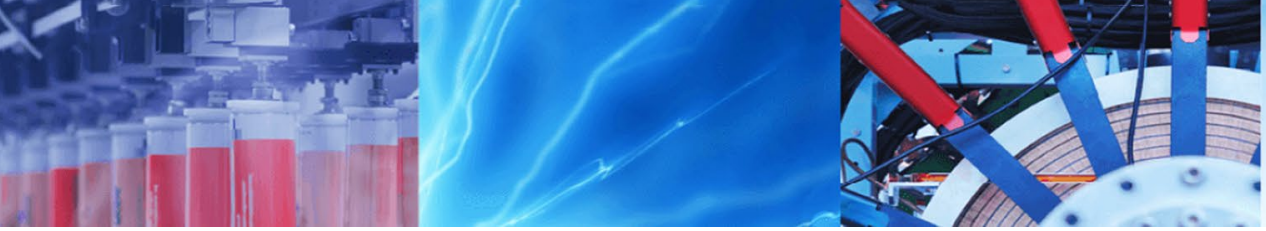

Research Article

\title{
Isolation and identification of metal-tolerant and antibiotic-resistant bacteria from soil samples of Cachar district of Assam, India
}

\author{
Soumitra Nath ${ }^{1}$ (D) Payal Paul ${ }^{1} \cdot$ Rajdeep Roy $^{1} \cdot$ Satabdi Bhattacharjee ${ }^{2} \cdot$ Bibhas Deb $^{1,2}$
}

(c) Springer Nature Switzerland AG 2019

\begin{abstract}
The present study aims to assess the physicochemical properties and prevalence of microbial communities in soils samples collected from different locations of Cachar district, Assam, India. Bacterial communities in the soil were screened by morphological, biochemical and 16S rDNA sequence analysis and were identified as Bacillus megaterium, Bacillus cereus, Pseudomonas aeruginosa and Chromobacterium pseudoviolaceum. High concentrations of toxic metals negatively affect bacterial growth, and therefore, the minimum inhibitory concentration of isolated bacteria was determined against $\mathrm{Cd}$, $\mathrm{Pb}, \mathrm{Fe}$ and $\mathrm{Cu}$ by agar dilution technique. Co-resistance of antibiotic was also determined, which demonstrated that most of the metal-tolerant isolates were resistant to Methicillin and Penicillin. However, P. aeruginosa showed resistance to other antibiotics such as Cefdinir, Ampicillin, Kanamycin, Rifampicin and Vancomycin. The development and evolution of antibiotic resistance in soil bacteria occurs very likely naturally as a result of unethical and non-scientific disposal of toxic substances and industrial discharge, which also includes heavy-metal effluents and other clinical by-products. Therefore, pragmatic measures must be taken to limit the spread of antimicrobial resistance across the environment and to reduce the incidence of healthcare-associated infections.
\end{abstract}

Keywords Toxic metal · Minimum inhibitory concentration · Antibiotic · Soil micro-organism · Agar dilution technique

\section{Introduction}

Soil contamination is caused by the presence of xenobiotic chemicals or other alterations in the natural soil environment. Contamination is typically caused by the accumulation of heavy metals and metalloids through emissions from the rapidly expanding industrial areas, disposal of high metal wastes, leaded gasoline and paints, etc. Application of fertilizers, sewage sludge, pesticides, wastewater irrigation, coal combustion residues, spillage of petrochemicals and atmospheric deposition from smelting also poses a threat to environmental sustainability [1]. Many studies demonstrated that soil pollution directly affects human health. Risks to human health arise from the contamination of elements such as arsenic, lead and cadmium, organic chemicals such as PCBs (polychlorinated biphenyls) and PAHs (polycyclic aromatic hydrocarbons) and pharmaceuticals such as antibiotics [2].

Heavy-metal concentrations highly influence the microbial communities by inhibiting metabolic functions and altering enzymes specificity. Heavy metals damage the cell membranes, disrupt cellular functions and denature DNA and proteins $[3,4]$. Heavy metals may also interfere with oxidative phosphorylation and osmotic balance [5]. However, micro-organisms also have their innate-tolerant ability to get adapted to the harsh environmental conditions [6]. Among the various adaptation mechanisms, the most commonly reported are metal sorption, mineralization, uptake and accumulation, extra-cellular precipitation, enzymatic oxidation or reduction to a less toxic form, and efflux of heavy metals from the cell [7]. Metal-removal efficiency varies among the micro-organisms, which

Soumitra Nath, nath.soumitra1@gmail.com | ${ }^{1}$ Department of Biotechnology, Gurucharan College, Silchar, Assam, India. ${ }^{2}$ Institutional Biotech Hub, Gurucharan College, Silchar, Assam, India.

SN Applied Sciences (2019) 1:727 | https://doi.org/10.1007/s42452-019-0762-3

Received: 27 February 2019 / Accepted: 11 June 2019 / Published online: 15 June 2019

SN Applied Sciences

A SPRINGER NATURE journal 
may be due to the genetic makeup of micro-organisms or the composition of the reduction medium [8]. Some studies showed that metals can trigger antibiotic resistance in the environment since the atmosphere favours the co-selection of metal and antibiotic resistance $[9,10]$. Environmental pollution by heavy metals not only triggers co-selection processes but also increases the level of tolerance to antibiotics due to co-regulation of resistance genes. Heavy-metal ions are known to co-regulate genes responsible for antibiotic resistance and decrease antibiotic susceptibility [11].

Therefore, the aim of the present study was to isolate and identify indigenous soil bacteria from contaminated sites and to determine microbial tolerance to heavy metal and co-resistance with antibiotics. The present study was conducted in the Cachar district of Assam, India, during the month of Jan-March, 2018. The average temperature was $11-23^{\circ} \mathrm{C}$, humidity $62-74 \%$, with no rainfall during the span of the study. The weather condition during the study was notably clear and mildly sunny with heavy fog during the night, which persisted till early morning.

\section{Materials and methods}

\subsection{Collection of soil samples}

Soil samples were collected from four different locations of Cachar district of Assam, India. The sampling sites were public grounds and uncultivable lands, located nearby paper industry, brick factories, garage and food industry. The nearby areas were not protected by nature reserve or any park, and therefore, no specific permission was required during sampling. At each sampling site, two soil cores were collected from the top horizon $(5-30 \mathrm{~cm}$ depth) that is considered to be biologically active with a strong hydrocarbon odour. The collected sub-samples were thoroughly mixed with a spade, and pooled into one composite sample per site. After sampling, the soil samples were transferred to plastic bags which were sealed and stored in a cold room (at $10^{\circ} \mathrm{C}$ ). Soil analyses were performed at Krishi Vigyan Kendra (KVK), Cachar, which includes determination of bulk density $(\mathrm{g} / \mathrm{mL})$, particle density $(\mathrm{g} / \mathrm{mL})$, porosity (\%), moisture content (\%), soil $\mathrm{pH}$, electrical conductivity, macronutrient ( $\mathrm{C}, \mathrm{N}, \mathrm{P}$ and $\mathrm{K}$ ) and micronutrient $(\mathrm{S}, \mathrm{Fe}, \mathrm{Zn}, \mathrm{B}$ and $\mathrm{Na}$ ) contents. Isolation and identification of bacteria were performed within $18 \mathrm{~h}$ of sample collection.

\subsection{Isolation and identification of bacteria}

Isolation and quantitative computation of bacteria from soil samples were performed by serial dilution technique
[12]. One hundred microlitres of samples was spread onto nutrient agar plates and incubated at $37^{\circ} \mathrm{C}$ for $24 \mathrm{~h}$. The total bacterial count was determined by counting the colonies in the microprocessor colony counter. Individual distinct colonies were sub-cultured and were identified by colony morphology, Gram's staining and biochemical tests (indole production, methyl red, Voges-Proskauer, citrate utilization, starch hydrolysis, etc.) [13]. Genomic DNA was extracted from isolated bacterial cultures [14], and PCR amplification of $16 \mathrm{~S}$ rDNA gene was achieved by 8F (5'-AGAGTTTGATCCTGGCTCAG-3') and 1492R (5'-GGT TACCTTGTTACGACTT-3') [15]. Sequencing of 165 rDNA was carried out at Xcelris Labs Limited, Gujarat, India, using ABI $3730 \times 196$ capillary system using Big Dye Terminator v3.1 kit. The consensus sequence of the 16S rDNA gene was generated from forward and reverse sequence data using aligner software. BLAST search was performed to find the closest homologous sequence, and based on the maximum identity score the first five sequences were selected. The nucleotide sequence thus obtained was analysed by Geneious R8 software package (Biomatters Ltd., Auckland, New Zealand). The $16 \mathrm{~S}$ rRNA gene sequences were aligned using Clustal-W, and the phylogenetic tree was constructed using PhyML [16].

\subsection{Assessment of bacterial tolerance to toxic metals}

Bacterial tolerance to cadmium ( $\mathrm{Cd})$, lead $(\mathrm{Pb})$, iron $(\mathrm{Fe})$ and copper ( $\mathrm{Cu}$ ) was determined by agar dilution method [17], which were added in the form of cadmium chloride, lead acetate, ferrous sulphate and copper (II) sulphate pentahydrate, respectively $[18,19]$. The initial concentration of these metal salts in nutrient plates was $50 \mu \mathrm{g} / \mathrm{mL}$, and bacterial growth was observed by streaking on respective plates. Metal concentration was progressively increased by $10-15 \mu \mathrm{g} / \mathrm{mL}$ on a fresh agar plate, and the MIC was noted when the isolates failed to grow on respective plates. The experiment was conducted separately for $\mathrm{Cd}, \mathrm{Pb}, \mathrm{Fe}$ and $\mathrm{Cu}$, taking five replicates at each concentration.

\subsection{Antibiotics sensitivity and resistance pattern}

Association of metal resistance with antibiotic resistance has been previously reported by many researchers [20], and therefore, the isolates were tested against 12 antibiotics using Kirby-Bauer disc diffusion technique [21]. Standard antibiotic discs were procured from 'HiMedia' which includes gentamicin $(50 \mu \mathrm{g})$, amikacin $(30 \mu \mathrm{g})$, cefalexin $(30 \mu \mathrm{g})$, methicillin $(30 \mu \mathrm{g})$, tetracycline $(30 \mu \mathrm{g})$, ceftriaxone $(30 \mu \mathrm{g})$, ampicillin $(25 \mu \mathrm{g})$, chloramphenicol $(10 \mu \mathrm{g})$, amoxicillin $(10 \mu \mathrm{g})$, kanamycin $(5 \mu \mathrm{g})$, ofloxacin $(5 \mu \mathrm{g})$ and cefixime $(5 \mu \mathrm{g})$. Antibiotic discs were placed on freshly 
prepared lawns of each isolate on Mueller-Hinton plates and incubated at $37^{\circ} \mathrm{C}$ for $24 \mathrm{~h}$. The diameter of each inhibition zone was measured, and the strains were classified as resistant $(R)$, intermediate $(I)$ or susceptible $(S)$ following the standard antibiotic disc chart.

\section{Results and discussion}

\subsection{Physical properties and fertility status of soil}

Analysis of soil samples revealed that the mean $\mathrm{pH}$ of the soil is $5.67 \pm 0.12$, which is slightly acidic and conducive to rice cultivation. Lower $\mathrm{pH}$ often increases the solubility of toxic metal ions, which are sometimes toxic to plants [22]. Essential elements such as zinc and boron were found to be deficient, whereas iron was found to be high, in the study area. The available sulphur varied from 3.7 to $8.3 \mathrm{ppm}$, and organic carbon content ranged from 0.32 to $0.53 \%$. Both were found to be deficient in the study area. The amount of available nitrogen $(\mathrm{N})$, phosphorous $(\mathrm{P})$ and potassium $(\mathrm{K})$ in soil samples is demonstrated in Table 1, which indicates the mean fertility index (NPK) of the study area as Low-Medium-Low. There was no definite trend in the distribution of essential elements in the soil, down the depth. The amount of sodium was found to be higher at the deeper horizons, probably due to illuviation and sodium saturation. The soil porosity decreased with increasing depth. Electrical conductivity ranged from 0.12 to $0.18 \mathrm{mS} / \mathrm{cm}$.

\subsection{Identification of metal-resistant bacteria}

A total of 57 isolates were recovered from four different locations. The culturable portion of the bacterial community appeared to be affected by the increasing concentration of each metal salts. Quantification of species diversity and studying their tolerance ability has been used to monitor the environmental hazards. Many researchers claimed that culturable soil bacteria are the most active and play a vital role in plant growth promotion and balancing soil nutrients [23]. The isolates which showed significant tolerance towards heavy metals were taken into consideration for identification.

Isolates designated as SO1 (site 1) and SO2 (from site 2) were gram-positive having opaque white colonies and did not show any pigmentation. Isolates $\mathrm{SO}_{3}$ (site 3) and $\mathrm{SO} 4$ (site 4) were gram-negative and showed pigmentation on the surface of culture media. Microscopic observation showed that all isolates were rod shaped, whereas sample SO4 was Coccobacillus. All strains were motile and aerobic. Biochemical test results demonstrated negative results for indole test, methyl red test and urease test. Positive results were observed for citrate test, nitrate reduction test, catalase test and gelatin hydrolysis. Samples $\mathrm{SO} 1$ and $\mathrm{SO} 2$ were positive for Voges-Proskauer test and starch hydrolysis; however, $\mathrm{SO} 3$ and SO 4 showed opposite results (Table 2).

\subsection{Molecular identification of bacteria}

$16 \mathrm{~S}$ rDNA sequence of the isolated bacteria was aligned using BLAST-N algorithm. Results of BLAST-N demonstrated that the query sequence has $97-99 \%$ identity and $100 \%$ query coverage with the $16 \mathrm{~S}$ rDNA of the bacterium recorded in the GenBank. Phylogenetic tree inferred the degree of relatedness between $16 \mathrm{~S}$ rDNA sequence of the isolates with other closely related $16 \mathrm{~S}$ rDNA sequences retrieved from the database (Fig. 1). Based on these data, the isolates were identified as Bacillus megaterium strain GCC-SO1, Bacillus cereus strain GCC-SO2, Pseudomonas aeruginosa strain GCC-SO3 and Chromobacterium pseudoviolaceum strain GCC-SO4, having GenBank accession numbers: MH109306, MH109312, MH109307 and MH109305, respectively. Bacillus sp. and Pseudomonas $\mathrm{sp}$. are the most commonly reported bacteria in soil, and possess much higher tolerance to heavy metals and other substances that are ever present in the environment [10, 24-28]. Dinucleotide repeats of eight bases (GCGCGCGC) were observed in all Bacillus sp. when compared with the aligned consensus sequence. On the other hand, seven nucleotide repeats (GTGGCGAGTGGCGA) were observed from position 89-104 bases of sample SO4 and few other Chromobacterium sp. A large deletion of nine bases (186-195 bases) was also observed Pseudomonas sp. and Chromobacterium sp. A higher GC proportion was observed in all the individual $16 \mathrm{~S}$ rDNA sequences. The GC $\%$ of isolate $\mathrm{SO} 1, \mathrm{SO} 2, \mathrm{SO} 3$ and $\mathrm{SO} 4$ was $53.62 \%, 53.62 \%$, $54.34 \%$ and $56.18 \%$, respectively. These variations in GC contents often guide in finding phylogenetic relationships among genus and species [29].

\subsection{Minimum inhibitory concentration}

Environmental contamination by toxic substances exerts selective pressure on soil microbes and thus leads to the development of resistance systems to virtually all toxic metals [30, 31]. Metal-tolerant bacteria have evolved various resistance and detoxification mechanisms, and the ability to tolerate toxic metals is mostly plasmid-mediated [32]. Heavy-metal toxicity in the soil is dependent on the geographical location, bacterial diversity and metal concentration. The present study demonstrates that Pseudomonas sp. can withstand a high level of environmental contaminants and toxic substances such as heavy metals and antibiotics. Heavy-metal tolerance by Pseudomonas sp. and Bacillus sp. has been reported by many researchers. 


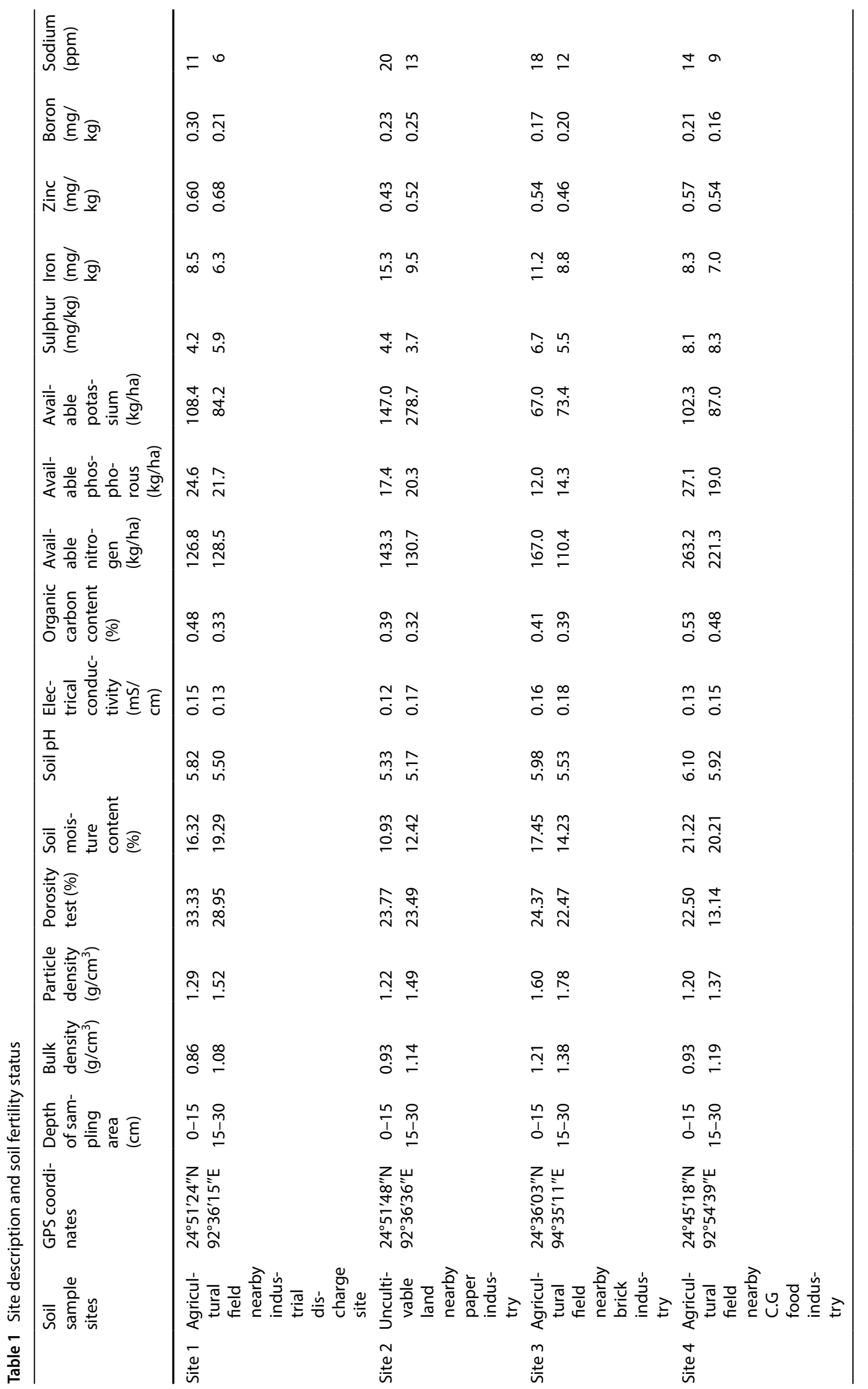


Table 2 Morphological and biochemical characteristics of isolated bacteria

\begin{tabular}{|c|c|c|c|c|}
\hline & Sample SO1 & Sample SO2 & Sample SO3 & Sample SO4 \\
\hline \multicolumn{5}{|l|}{ General characteristics } \\
\hline Colony characteristics & Circular, opaque & Spread, irregular colony & Moist, translucent & Circular, raised \\
\hline Size & Large & Large & Small & Small \\
\hline Pigmentation & - & - & Yellow & Violet \\
\hline Colour & White colonies & White colonies & Yellow-green colonies & Violet colonies \\
\hline Margin & Entire & Wrinkled & Entire & entire \\
\hline Motility & Motile & Motile & Motile & Motile \\
\hline Growth condition & Aerobic & Aerobic & Aerobic & Aerobic \\
\hline Gram staining & Gram-positive, rod shape & Gram-positive, rod shape & Gram-negative, rod shape & $\begin{array}{c}\text { Gram-nega- } \\
\text { tive, Coc- } \\
\text { cobacillus }\end{array}$ \\
\hline \multicolumn{5}{|c|}{ Biochemical characteristics } \\
\hline Indole & - & - & - & - \\
\hline MR & - & - & - & - \\
\hline VP & + & + & - & - \\
\hline Citrate & + & + & + & + \\
\hline Nitrate reduction & + & + & + & + \\
\hline Starch hydrolysis & + & + & - & - \\
\hline Urease test & - & - & - & - \\
\hline Catalase test & + & + & + & + \\
\hline Gelatin hydrolysis & + & + & + & + \\
\hline Oxidase & - & + & + & + \\
\hline
\end{tabular}

' + 'Indicates positive results, and '-'indicates negative results for respective tests

Some of their strains also play an important role in the remediation of organic and inorganic contaminants from the environment [33-35]. In the present study, B. cereus strain GCC-SO2 showed a much higher degree of tolerance towards lead and copper with MIC of $2050 \pm 50$ and $1716.66 \pm 76.37 \mu \mathrm{g} / \mathrm{mL}$, respectively. The strains of Bacillus sp., however, failed to withstand a high concentration of cadmium. Maximum tolerance towards cadmium and iron was shown by $P$. aeruginosa strain GCC-SO3, lead by $B$. cereus strain GCC-SO2 and B. megaterium strain GCC-SO1, and copper by B. cereus strain GCC-SO2 (Table 3). A promising result on the biosorption capability of cadmium and aluminium by Bacillus sp. has been reported by Arivalagan et al. [15] and Dhanarani et al. [36]. Chromobacterium pseudoviolaceum strain GCC-SO4 isolated in the present study showed significant tolerance to all tested metals, which is evidenced by other researchers [37, 38]. However, very less studies have been carried out on the abilities of $C$. pseudoviolaceum and their long-term application in bioremediation of metal-polluted soil. Oladipo et al. [39] reported that metal uptake rates and intra-cellular accumulation of heavy metals exceed the rate of extra-cellular loss. The differential quantities of metals accumulation by various isolates differ with the cell wall structures, as well as the synthesis of metalloproteins [40].

\subsection{Antibiotics sensitivity and resistance pattern of isolated bacteria}

Heavy-metal ions are known to co-regulate genes responsible for antibiotic resistance and decrease antibiotic susceptibility [41]. It has been observed that all the isolated strains were resistant to Methicillin and Penicillin. P. aeruginosa strain GCC-SO3, however, showed resistance to Cefdinir, Ampicillin, Kanamycin, Rifampicin and Vancomycin. B. megaterium strain GCC-SO1, B. cereus strain GCC-SO2 and C. pseudoviolaceum strain GCC-SO4 showed an intermediate zone of inhibition against Azithromycin, Ceftriaxone, Cefdinir, Rifampicin, Polymyxin and Co-trimoxazole (Table 4). Environmental pollution not only triggers heavy-metal co-selection processes but also increases the level of tolerance to some antibiotics due to co-regulation of resistance genes [42]. The combined expression of antibiotic and heavy-metal resistance by $B$. cereus and $P$. aeruginosa may not be a chance phenomenon but rather a result of selection by heavy metal present in an environment $[26,36,43]$. Therefore, pragmatic measures must be taken to limit the spread of antimicrobial resistance across the environment and to reduce the incidence of healthcareassociated infections. 


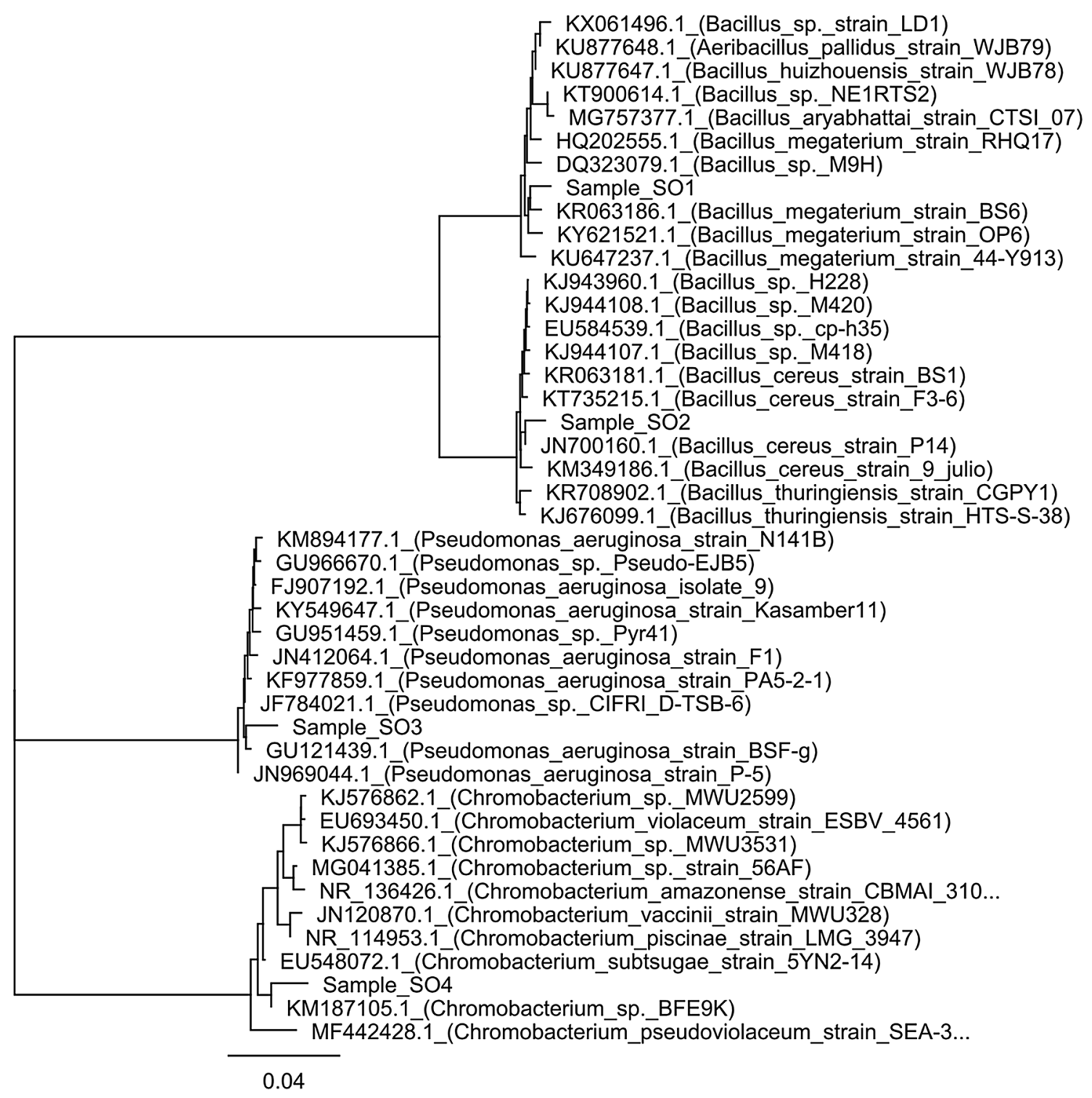

Fig. 1 Neighbour-joining tree, showing the phylogenetic relationship of sample SO1, SO2, SO3 and SO4 with closely related species

Table 3 Minimum inhibitory concentration of isolated bacteria against $\mathrm{Cd}, \mathrm{Pb}$, Fe and $\mathrm{Cu}$ (expressed in $\mu \mathrm{g} / \mathrm{mL}$ of $\mathrm{NA}$ )

\begin{tabular}{lrrrl}
\hline & $\begin{array}{l}\text { Bacillus megate- } \\
\text { rium strain GCC- } \\
\text { SO1 }\end{array}$ & $\begin{array}{l}\text { Bacillus cereus } \\
\text { strain GCC-SO2 }\end{array}$ & $\begin{array}{l}\text { Pseudomonas aerugi- } \\
\text { nosa strain GCC-SO3 }\end{array}$ & $\begin{array}{l}\text { Chromobacterium } \\
\text { pseudoviolaceum strain } \\
\text { GCC-SO4 }\end{array}$ \\
\hline Cadmium & $33.33 \pm 28.86$ & $483.33 \pm 76.37$ & $1516.67 \pm 76.37$ & $1166.67 \pm 57.73$ \\
Lead & $1650.00 \pm 50.00$ & $2050.00 \pm 50.00$ & $966.66 \pm 57.73$ & $1350.00 \pm 50.00$ \\
Iron & $583.33 \pm 28.86$ & $716.66 \pm 76.37$ & $1633.33 \pm 28.86$ & $1183.33 \pm 76.37$ \\
Copper & $2383.33 \pm 28.86$ & $2533.33 \pm 57.73$ & $1716.66 \pm 76.37$ & $1683.33 \pm 28.86$ \\
\hline
\end{tabular}

The values are the mean of three independent replications \pm SE 
Table 4 Antibiotic sensitivity and resistance pattern of isolated bacteria (expressed in $\mathrm{mm}$ )

\begin{tabular}{|c|c|c|c|c|}
\hline Name of antibiotics & $\begin{array}{l}\text { Bacillus megaterium strain } \\
\text { GCC-SO1 }\end{array}$ & $\begin{array}{l}\text { Bacillus cereus strain } \\
\text { GCC-SO2 }\end{array}$ & $\begin{array}{l}\text { Pseudomonas aeruginosa } \\
\text { strain GCC-SO3 }\end{array}$ & $\begin{array}{l}\text { Chromobacterium } \\
\text { pseudoviolaceum strain } \\
\text { GCC-SO4 }\end{array}$ \\
\hline Methicillin & $\mathrm{NI}$ & $\mathrm{NI}$ & $\mathrm{NI}$ & $\mathrm{NI}$ \\
\hline Azithromycin & 18 & 15 & 9 & 14 \\
\hline Ceftriaxone & 15 & 18 & 30 & 12 \\
\hline Cefdinir & 14 & 11 & $\mathrm{NI}$ & 14 \\
\hline Co-trimoxazole & 16 & 12 & 13 & 9 \\
\hline Ampicillin & 10 & 9 & $\mathrm{NI}$ & 9 \\
\hline Ofloxacin & 24 & 20 & 30 & 28 \\
\hline Ciprofloxacin & 24 & 21 & 43 & 32 \\
\hline Norfloxacin & 19 & 17 & 35 & 20 \\
\hline Kanamycin & 18 & 7 & $\mathrm{NI}$ & 20 \\
\hline Amoxiclav & 24 & 17 & 26 & 20 \\
\hline Meropenem & 40 & 26 & 37 & 35 \\
\hline Streptomycin & 25 & 20 & 22 & 22 \\
\hline Penicillin & $\mathrm{NI}$ & $\mathrm{NI}$ & $\mathrm{NI}$ & $\mathrm{NI}$ \\
\hline Tetracyclin & 28 & 18 & 14 & 27 \\
\hline Rifampicin & 12 & 9 & $\mathrm{NI}$ & 13 \\
\hline Amikacin & 23 & 20 & 19 & 23 \\
\hline Gentamicin & 24 & 24 & 34 & 24 \\
\hline Polymyxin B & 12 & 11 & 13 & 11 \\
\hline Vancomycin & 15 & 12 & $\mathrm{NI}$ & 25 \\
\hline
\end{tabular}

$N /$ no inhibition zone; diameter of disc $=6 \mathrm{~mm}$

\section{Conclusion}

The crop field nearby paper industry, brick factories, garage and food industry instigate microbial resistance towards toxic metals. The study demonstrates metal tolerance by $B$. megaterium strain GCC-SO1, B. cereus strain GCC-SO2, P. aeruginosa strain GCC-SO3 and C. pseudoviolaceum strain GCC-SO4. Isolated strains of Bacillus sp. exert maximum tolerance against lead and copper, and Pseudomonas sp. against cadmium and iron. Chromobacterium sp., however, showed a significant tolerance towards all tested metals. Co-selection of antibiotic resistance has also been observed, which may be the result of selection of heavy-metal tolerance by the isolated strains. Therefore, metal contamination represents a long-standing, widespread and recalcitrant selection pressure with both environmental and clinical importance that potentially contributes to the maintenance and spread of antibiotic resistance factors.

Acknowledgements The authors extend their thanks to the Department of Biotechnology (DBT), New Delhi, for the establishment of Institutional Biotech Hub and Bioinformatics Centre in Gurucharan College, Silchar, India. All the staff members of Krishi Vigyan Kendra (KVK), Masimpur, India, are acknowledged for necessary guidance during soil sampling and analysis. Authors are also grateful to Mehdi
Hasan Chowdhury for providing valuable suggestions in writing the manuscript.

\section{Compliance with ethical standards}

Conflict of interest The authors declare that there is no competing interest.

\section{References}

1. Zhang $M-K$, Liu Z-Y, Wang $H$ (2010) Use of single extraction methods to predict bioavailability of heavy metals in polluted soils to rice. Commun Soil Sci Plant Anal 41(7):820-831

2. Steffan J, Brevik E, Burgess L, Cerdà A (2018) The effect of soil on human health: an overview. Eur J Soil Sci 69(1):159-171

3. Zhang C, Nie S, Liang J, Zeng G, Wu H, Hua S, Liu J, Yuan Y, Xiao $H$, Deng $L$ (2016) Effects of heavy metals and soil physicochemical properties on wetland soil microbial biomass and bacterial community structure. Sci Total Environ 557:785-790

4. Xie Y, Fan J, Zhu W, Amombo E, Lou Y, Chen L, Fu J (2016) Effect of heavy metals pollution on soil microbial diversity and bermudagrass genetic variation. Front Plant Sci 7:755

5. Poole RK, Gadd GM (1989) Metal-microbe interactions. Published for the Society for General Microbiology by IRL Press

6. Karthik C, Ramkumar VS, Pugazhendhi A, Gopalakrishnan K, Arulselvi PI (2017) Biosorption and biotransformation of $\mathrm{Cr}(\mathrm{VI})$ by novel Cellulosimicrobium funkei strain AR6. J Taiwan Inst Chem Eng 70:282-290 
7. Mergeay M (1991) Towards an understanding of the genetics of bacterial metal resistance. Trends Biotechnol 9(1):17-24

8. Jacob JM, Karthik C, Saratale RG, Kumar SS, Prabakar D, Kadirvelu K, Pugazhendhi A (2018) Biological approaches to tackle heavy metal pollution: a survey of literature. J Environ Manage 217:56-70

9. Imran M, Das KR, Naik MM (2018) Co-selection of multi-antibiotic resistance in bacterial pathogens in metal and microplastic contaminated environments: an emerging health threat. Chemosphere 215:846

10. Nath S, Deb B, Sharma I (2012) Isolation and characterization of cadmium and lead resistant bacteria. Global Adv Res J Microbiol 1(11):194-198

11. Baker-Austin C, Wright MS, Stepanauskas R, McArthur J (2006) Co-selection of antibiotic and metal resistance. Trends Microbiol 14(4):176-182

12. Harrigan WF, McCance ME (2014) Laboratory methods in microbiology. Academic Press, Cambridge

13. Holt G, Keong N, Sneath P, Staley J (1994) Bergey's manual of determinative bacteriology. Williams and Wilkins Press, Baltimore

14. Green MR, Sambrook J (2012) Molecular cloning: a laboratory manual, vol 1. Cold Spring Harbor Laboratory Press, New York

15. Arivalagan P, Singaraj D, Haridass V, Kaliannan T (2014) Removal of cadmium from aqueous solution by batch studies using Bacillus cereus. Ecol Eng 71:728-735

16. Guindon S, Dufayard J-F, Lefort V, Anisimova M, Hordijk W, Gascuel O (2010) New algorithms and methods to estimate maximum-likelihood phylogenies: assessing the performance of PhyML 3.0. Syst Biol 59(3):307-321

17. Abou-Shanab R, Van Berkum P, Angle J (2007) Heavy metal resistance and genotypic analysis of metal resistance genes in gram-positive and gram-negative bacteria present in $\mathrm{Ni}$ rich serpentine soil and in the rhizosphere of Alyssum murale. Chemosphere 68(2):360-367

18. Pandey S, Ghosh PK, Ghosh S, De TK, Maiti TK (2013) Role of heavy metal resistant Ochrobactrum sp. and Bacillus spp. strains in bioremediation of a rice cultivar and their PGPR like activities. J Microbiol 51(1):11-17

19. Mohamed RM, Abo-Amer AE (2012) Isolation and characterization of heavy-metal resistant microbes from roadside soil and phylloplane. J Basic Microbiol 52(1):53-65

20. Rani MJ, Hemambika B, Hemapriya J, Kannan VR (2010) Comparative assessment of heavy metal removal by immobilized and dead bacterial cells: a biosorption approach. Afr J Environ Sci Technol 4(2):077-083

21. Baccer R, Kirby M, Sherris J, Turek M (1966) Antibiotic susceptibility testing by standard single disc diffusion method. Am J Clin Pathol 45:493-496

22. Hobley EU, Wilson B (2016) The depth distribution of organic carbon in the soils of eastern Australia. Ecosphere 7(1):e01214

23. Ellis RJ, Morgan P, Weightman AJ, Fry JC (2003) Cultivationdependent and-independent approaches for determining bacterial diversity in heavy-metal-contaminated soil. Appl Environ Microbiol 69(6):3223-3230

24. Abbas S, Ahmed I, Kudo T, Iqbal M, Lee Y-J, Fujiwara T, Ohkuma M (2015) A heavy metal tolerant novel bacterium, Bacillus malikii sp. nov., isolated from tannery effluent wastewater. Antonie Van Leeuwenhoek 108(6):1319-1330

25. Cui X, Wang Y, Liu J, Chang M, Zhao Y, Zhou S, Zhuang L (2015) Bacillus dabaoshanensis sp. nov., a $\mathrm{Cr}(\mathrm{VI})$-tolerant bacterium isolated from heavy-metal-contaminated soil. Arch Microbiol 197(4):513-520
26. Shammi T, Ahmed S (2016) Heavy metal tolerance and antibiotic resistance of Bacillus spp isolated from two major rivers in Bangladesh. Bangladesh J Microbiol 30(1-2):17-22

27. Jayanthi B, Emenike C, Agamuthu P, Simarani K, Mohamad S, Fauziah S (2016) Selected microbial diversity of contaminated landfill soil of Peninsular Malaysia and the behavior towards heavy metal exposure. CATENA 147:25-31

28. Nath S, Deb B, Sharma I, Pandey P (2014) Role of cadmium and lead tolerant $P$. aeruginos $a$ in seedling germination of rice (Oryza sativa L.). J Environ Anal Toxicol 4(221):2161-0525

29. Parker J (2001) Base composition A2-Brenner, sydney. In: Miller JH (ed) Encyclopedia of genetics. Academic Press, New York, p 192. https://doi.org/10.1006/rwgn.2001.0115

30. Gu Y, Van Nostrand JD, Wu L, He Z, Qin Y, Zhao F-J, Zhou J (2017) Bacterial community and arsenic functional genes diversity in arsenic contaminated soils from different geographic locations. PLoS ONE 12(5):e0176696

31. Cabral L, Júnior GVL, de Sousa STP, Dias ACF, Cadete LL, Andreote FD, Hess M, de Oliveira VM (2016) Anthropogenic impact on mangrove sediments triggers differential responses in the heavy metals and antibiotic resistomes of microbial communities. Environ Pollut 216:460-469

32. Rajkumar M, Ae N, Prasad MNV, Freitas H (2010) Potential of siderophore-producing bacteria for improving heavy metal phytoextraction. Trends Biotechnol 28(3):142-149

33. Pugazhendhi A, Ranganathan K, Kaliannan T (2018) Biosorptive removal of copper (II) by Bacillus cereus isolated from contaminated soil of electroplating industry in India. Water Air Soil Pollut 229(3):76

34. Karthik C, Barathi S, Pugazhendhi A, Ramkumar VS, Thi NBD, Arulselvi PI (2017) Evaluation of $\mathrm{Cr}(\mathrm{VI})$ reduction mechanism and removal by Cellulosimicrobium funkei strain AR8, a novel haloalkaliphilic bacterium. J Hazard Mater 333:42-53

35. Pugazhendhi A, Boovaragamoorthy GM, Ranganathan $K$, Naushad M, Kaliannan T (2018) New insight into effective biosorption of lead from aqueous solution using Ralstonia solanacearum: characterization and mechanism studies. J Clean Prod 174:1234-1239

36. Dhanarani $S$, Viswanathan E, Piruthiviraj $P$, Arivalagan $P$, Kaliannan T (2016) Comparative study on the biosorption of aluminum by free and immobilized cells of Bacillus safensis KTSMBNL 26 isolated from explosive contaminated soil. J Taiwan Inst Chem Eng 69:61-67

37. Brandl H, Faramarzi MA (2006) Microbe-metal-interactions for the biotechnological treatment of metal-containing solid waste. China Particuol 4(2):93-97

38. Carepo MS, Azevedo J, Porto Jl, Bentes-Sousa AR, Batista Jda S, Silva A, Schneider M (2004) Identification of Chromobacterium violaceum genes with potential biotechnological application in environmental detoxification. Genet Mol Res 3(1):181-194

39. Oladipo OG, Ezeokoli OT, Maboeta MS, Bezuidenhout JJ, Tiedt LR, Jordaan A, Bezuidenhout CC (2018) Tolerance and growth kinetics of bacteria isolated from gold and gemstone mining sites in response to heavy metal concentrations. J Environ Manage 212:357-366

40. Mosa KA, Saadoun I, Kumar K, Helmy M, Dhankher OP (2016) Potential biotechnological strategies for the cleanup of heavy metals and metalloids. Front Plant Sci 7:303

41. Zhai Y, He Z, Kang Y, Yu H, Wang J, Du P, Zhang Z, Hu S, Gao Z (2016) Complete nucleotide sequence of $\mathrm{pH} 11$, an IncHI2 plasmid conferring multi-antibiotic resistance and multi-heavy metal resistance genes in a clinical Klebsiella pneumoniae isolate. Plasmid 86:26-31 
42. Seiler C, Berendonk TU (2012) Heavy metal driven co-selection of antibiotic resistance in soil and water bodies impacted by agriculture and aquaculture. Front Microbiol 3:399

43. Nath S, Deb B, Sharma I (2018) Isolation of toxic metal-tolerant bacteria from soil and examination of their bioaugmentation potentiality by pot studies in cadmium-and lead-contaminated soil. Int Microbiol 21:1-2
Publisher's Note Springer Nature remains neutral with regard to jurisdictional claims in published maps and institutional affiliations. 